\title{
SIMULATION OF DECLINE OF NORWAY SPRUCE (Picea abies L. Karst.) FORESTS IN GORGAN MOUNTAINS (UKRAINIAN CARPATHIANS): CASE STUDY USING FORKOME MODEL
}

\author{
TARAS PARPAN ${ }^{1}$, IHOR KOZAK ${ }^{2,3}$, YURIY SHPARYK ${ }^{1}$, MYROSLAVA MYLENKA ${ }^{3}$, \\ IVAN BALANIUK ${ }^{4}$
}

${ }^{1}$ Ukrainian Research Institute for Mountain Forestry, Ivano-Frankivsk, Ukraine; e-mail: tarasparpan@gmail.com ${ }^{2}$ Department of Landscape Ecology, John Paul II Catholic University in Lublin, Konstantynow 1H, 20-708 Lublin, Poland; e-mail: modeliho@kul.lublin.pl

${ }^{3}$ Department of Biology and Ecology, Vasyl Stefanyk Precarpathian National University, Shevchenko str., 57, 76010, Ivano-Frankivsk, Ukraine; e-mail: kozakihor58@gmail.com, mulenka.m@gmail.com

${ }^{4}$ Department of Accounting and Auditing, Vasyl Stefanyk Precarpathian National University, Shevchenko str., 57, 76010, Ivano-Frankivsk, Ukraine; e-mail: ifbalaniuk@gmail.com

\begin{abstract}
Parpan T., Kozak I., Shparyk Y., Mylenka M., Balaniuk I.: Simulation of decline of Norway spruce (Picea abies L. Karst.) forests in Gorgan Mountains (Ukrainian Carpathians): case study using FORKOME model. Ekológia (Bratislava), Vol. 38, No. 4, p. 353-366, 2019.

The FORKOME model used in the article contains elements of forest and ecological approaches and was specially developed for the conditions of the Gorgans. The modeling was performed based on the single simulation results and statistically averaged forecast of 200 simulations ("Monte Carlo") in order to show the tendency of changes and their correspondence with single simulations. The forecast of the forest dynamics was conducted at the 100th anniversary period with "control" and "warm-dry" scenarios. It has been revealed that the rapid decrease in biomass in the first decade was caused by Norway spruce decline. It was revealed that in the control scenario, the most active biomass growth during the 100th year forecast was shown by Silver fir (Abies alba Mill.) and beech (Fagus sylvatica L.). The fir reacted relatively sensitively to the warming and decrease in rainfall. The relationships between tree species and the influence of biomass of Norway spruce tree on the biomass of the whole forest tree stand were analyzed.
\end{abstract}

Key words: modeling, biomass, number of trees, forecast.

\section{Introduction}

For the past two centuries, the extensive planting of Norway spruce (Picea abies L. Karst.) has been a characteristic method of forest management for Central Europe. Norway spruce monocultures take up considerable areas in the Ukrainian Carpathians (Holubets, 1978). Nowadays, under changing climatic conditions, modified forest ecosystems have been rapid- 
ly losing their vitality and resistance against destructive abiotic and biotic impacts (Spiecker et al., 2004; Shparyk, 2014, 2019). At the present time, a decline in Norway spruce forests is made visible on the area of 19,300 ha of forest (3\% of whole Norway spruce in the Ukrainian Carpathians) with a wood volume of 5.8 million $\mathrm{m}^{3}$ (Parpan et al., 2014).

Norway spruce mortality was evenly recorded in different regions across all slope expositions (Mandre, 1992). The infestation intensity increased slightly with Norway spruce representation in the stands and was higher in stands older than 80 years (Kozak, Menshutkin, 2001; Grodzki et al., 2014), and defoliation of trees influences the increment and destruction of tree stand structure.

At that time, Norway spruce mortality was recorded in Ukraine as a national problem (Parpan et al., 2014). Studies on the type and scope of diseases and pests and on the methods of sanitary measures of Norway spruce forests in the area of Carpathian were conducted (Turis, Shanta, 2013). Causes of Norway spruce forests drying in the Precarpathians are considered; groups of factors that make this negative process are identified and characterized (Debryniuk, 2011). Conversion of an even-aged secondary Norway spruce into uneven-aged mixed stands in the Carpathian Mountains, as in whole Central Europe, is internationally thought as a main challenge of the recent mountain forest management (Lavnyy, Schnitzler, 2014). The simulation of conversion strategies for a 62-year even-aged secondary Norway spruce site located in Transcarpathian region of the Ukrainian Carpathians was conducted using the growth simulator SIBYLA (Fabrika, 2005).

One of the reasons of decline of Norway spruce forest is global warming. For the past 100 years (1906-2005), the average global temperature has increased by approximately $0.74{ }^{\circ} \mathrm{C}$ (IPCC, 2007). During the same period, the average temperature in Europe increased even more by $0.95{ }^{\circ} \mathrm{C}$. According to the forecasts formulated by the Intergovernmental Panel on Climate Change (IPCC), a further significant increase in the average annual temperature in Europe is expected by the end of the 21 st century. It is estimated that for the next 100 years, temperatures in Europe will increase from 2.0 to $6.3{ }^{\circ} \mathrm{C}$ (IPCC, 2007). The sum of precipitation and the frequency of extreme weather events are also expected to increase (Lindner et al., 2010). At that time, Norway spruce stands in Ukrainian Carpathians grows in the warm temperature belt (Parpan et al., 2014).

Forests are particularly sensitive to climate change, because the long life of trees does not allow for quick adaptation to environmental changes (Linder et al., 2010). Owing to climate change, there are a number of factors affecting forest ecosystems that can function independently or in combination. These factors are temperature changes and rainfall. The occurrence of meteorological phenomena, although they are natural processes occurring in the atmosphere, negatively affects forests, causing very dangerous consequences (Durlo, 2011). The changes taking place in the environment have occurred so quickly that the Norway spruce has not managed to adapt to them.

The forecasting of dynamics of decline Norway spruce forest stands requires the use of special tools, that is, properly designed computer models. Therefore, an attempt was made to use the FORKOME model to carry out prognostic simulations of possible changes in factors affecting the dieback of Norway spruce. Autocorrelation and cross-correlation function were added to the FORKOME model and can also be considered as coefficients of mutual influ- 
ence (Jørgensen, 1994). Interesting is the analysis of the relationships (correlations) between decline Norway spruce and others tree species in the forest tree stands.

Taking these reflections into consideration, the main objective of this article is to perform the forecasts of biomass and number of trees in decline Norway spruce stands in Gorgans (Ukraine) in control (actual temperature and precipitation) and in warm-dry scenario (with increase $200^{\circ}$ degree-days temperature and decrease $200 \mathrm{~mm}$ precipitation). Additional aim was to conduct cross-correlation analysis between biomass of tree species in the decline forest stand using the FORKOME computer model.

\section{Material and methods}

Specificity of decline of Norway spruce stand is analyzed in research plot situated in the Ukrainian Gorgans (Ludvykivka Department, Vygoda State Forestry Enterprise, Ivano-Frankivsk Regional Forestry and Hunting Administration). This plot was located in compartment 14, subcompartment 42 (N: 48047'30,5", E 23043'53,7") on the northern slope of the mountain at an inclination of $18^{\circ}$ and altitude of $800 \mathrm{~m}$ a.s.l. in wet mesotrophic Silver fir - Common beech - Norway spruce forest type. The brown soil covering the Carpathian flysch is a characteristic for plot, which was covered by Norway spruce, fir (Abies alba Mill.), sycamore (Acer pseudoplatanus L.), and birch (Betula pendula Roth.) trees. The average diameters (DBH1,3), heights $(\mathrm{H})$, and age are presented in Table 1.

T a b l e 1. Basic characteristics of the all trees in research plot.

\begin{tabular}{|c|c|c|c|c|c|c|c|c|c|c|}
\hline Species & & $\mathrm{BH}(\mathrm{c}$ & & & H (m) & & & e (yea & & $\mathbf{N}$ \\
\hline & mean & $\min$ & $\max$ & mean & $\min$ & $\max$ & mean & $\min$ & $\max$ & \\
\hline Picea abies & 31.1 & 7.1 & 72.4 & 27.5 & 4 & 45 & 77 & 20 & 120 & 146 \\
\hline Abies alba & 25.3 & 6.35 & 80.1 & 20.5 & 5 & 44 & 56 & 20 & 119 & 78 \\
\hline Acer pseudoplatanus & 34.5 & 15.9 & 57.7 & 27.1 & 9 & 41.5 & 84 & 26 & 119 & 15 \\
\hline Betula pendula & 29 & 21.9 & 36.6 & 26 & 20.7 & 32.5 & 72 & 33 & 112 & 6 \\
\hline
\end{tabular}

The dimension of the research plot was $50 \times 60 \mathrm{~m}$. Such size is often used in gap models (Bugmann, 2001). After conducting 200 test simulations for each study plot, it was found that the area observed corresponded to the district with the area of $200 \times 300=60.0$ ha. The statistical analysis of the obtained data (the Shapiro-Wilk test performed using STATISTICA 13.1.) showed that the DBH of the examined trees had normal distribution with marked rightsided asymmetry and (the regression analysis) allow to create prediction equation for $P$. abies biomass changes in control and in warm-dry climate conditions.

The trees observed on the study plots were numbered and their $\mathrm{DBH}$, height, crown radius, age, as well as $\mathrm{X}$ and Y coordinates were recorded. Hemispherical photographs (in 9 sites on the study plot) were taken as required for verifying the leaf area index (LAI) calculations performed by FORKOME. A digital SLR camera Canon EOS 5D with Sigma $8 \mathrm{~mm}$ f/3.5 DG EX FISH EYE with $180^{\circ}$ viewing angle was used. Gap Light Analyzer software (Frazer et al., 2000) was used for hemispherical analyses.

All the data collected from the study plots were entered into the model FORKOME (Kozak et al., 2012), and simulations of stand development for a period of 100 years were carried out (such a long simulation period was needed for stabilizing relationships among Norway spruce, fir, and beech which appeared in the process of forecasting on the research plots).

The model FORKOME belongs to the group of gap models that simulate the long-term dynamics (succession) of forest complexes, taking directly into account the influence of the most important environmental factors, such as temperature, precipitation, light, and soil nutrient content, on the main processes taking place in the stands: regeneration, growth, and decline in individual trees. The design and structure of FORKOME were described in detail in earlier publications, and FORKOME model was verified for Ukraine, Poland, and Sweden (Kozak, Menshutkin, 2002; Kozak et al., 2007, 2012). In particular, a large number of modifications and new solutions to the model were introduced in block of natural disasters. 
FORKOME represents a patch-model family that simulates the forest association succession, allowing single tree research, and herein, it is divided into blocks. The following two kinds of analysis are possible with FORKOME: (1) statistical analysis with mean value and standard variation and (2) sensitivity analysis in a series of autocorrelation and cross-correlation function calculations. This model sets site, species, climate, and felling parameters, and result-saving and additional analysis by other computer methodology and programmers is also possible. The Monte Carlo statistical method allows simulation of up to 200 variants for each scenario. The model delivers the average amount and average biomass of trees with the standard variation in each year. Autocorrelation and cross-correlation functions are included to improve the sensitivity of the analysis of the forest ecosystems. The number of trees and their biomass are important parameters in these calculations, and available charts present the relationships between these parameters and temperature and humidity for each species and for the entire association.

In the FORKOME model, the "growth bloc" simulates the actual annual tree growth on the studied area. Although each tree has its own genetically coded method of growth, its growth process is also influenced by its environment. The FORKOME model's trees are also described by species-specific growth function, with the main parameters of $\mathrm{DBH}$, height $(\mathrm{H})$, and age, together with the external conditions of the individual patch area. This approach simplifies the growth simulation and allows growth-function activation and implementation in current conditions. The basic simulation consists of the tree diameter calculation, where the annual diameter increase ranges from the minimal value of 0 to the maximum value for each species under ideal conditions (Kozak et al., 2012).

The influence of external conditions is factored into the annual tree volume increase process. The actual tree increase $\delta\left(D^{2} H\right)_{\text {real }}$ results from the optimal increase $\delta\left(D^{2} H\right)_{o p t}$ and tree growth inhibiting conditions $f 1, f 2, \ldots . . f$, where the value of each tree-growth-inhibiting factor ranges from 0 to 1 .

Light availability is the most important external factor inhibiting tree growth, and in FORKOME, this is calculated with consideration of light radiation loss. This loss is caused by the total shading by the leaf area of higher trees.

The available light function describes the amount of light available for specific tree leaves. Trees are divided into the following 3 types based on their light tolerance index: sun tolerant, medium, and shade tolerant.

The tree-growth-inhibiting light index is called the light reaction function, and this is calculated in two different ways depending on tree-light tolerance index. This model's thermal conditions are described by the addition of annual effective temperatures above $5^{\circ}$, and the temperature index inhibiting the tree growth can be calculated (Botkin, 1993).

The FORKOME model also considers leaf transpiration, and this depends not only on the meteorological conditions but also on the tree species, as in other patch models. There also exist relationships between tree species and ground water level and between tree growth speed and the availability of ground water implemented in the model structure. The bloc is created by the basic water balance equation (Kozak et al., 2012).

A further tree-growth-inhibiting index is the SITE INDEX that describes the ratio of steam-occupied area to the maximum available area (Botkin, 1993).

A tree can perish in the following two ways in the FORKOME model: (1) randomly or (2) if it does not reach minimum diameter size. The model asserts that if the tree does not increase its diameter every year for 10 years, then there is only a $1 \%$ chance that the tree will survive that period. The MORTAL statistical probability for annual tree death is 0.386 .

The FORKOME model is able to confirm the tree's minimal increase. If the minimum value is not exceeded, then it is assigned its random probability from 0 to 1 , and when that value is greater than 0.386 , the tree is removed.

Autocorrelation and cross-correlation functions are included to improve the sensitivity analysis of the forest ecosystems. The number of trees and their biomass are important parameters in these calculations, and the available charts present the relationships between these parameters and temperature and humidity for each species and for the entire association.

Autocorrelation function was calculated based on the equation:

$$
A C(X, \tau)=\frac{\left.\sum_{t=0}^{t_{\max }-\tau}\{X(t)-\bar{X}] *[X(t-\tau)-\bar{X}]\right\}}{\left|\sum_{t=0}^{t_{\max }}[X(t)-\bar{X}]^{2}\right|} * \frac{t_{\max }}{t_{\max }-\tau}
$$

$\mathrm{AC}(\mathrm{X}, \mathrm{t})$ is the autocorrelation coefficient for $\mathrm{X}$; $\mathrm{X}$ is the parameter for autocorrelation analysis; 
$\mathrm{X}$ is the arithmetic mean for $\mathrm{X}$;

$\mathrm{t}$ is the time in the model;

$\tau$ is the time interval.

The current version of the FORKOME model has been verified using the data from 2010 to 2014 and up to 2016. After running the model on the data for 2010, the forecast to 2014 and to 2016 was realized. The model represented $90 \%$ real-field data from 2014 and $87 \%$ from 2016 year and showed good verification (prognosticity) for the stochastic models. After that, the prognosis was made for the next 94 years (total time of simulations run equal 100 years).

The special "DRYING" block has been added to the FORKOME model. While working on the prediction of drying of Norway spruce forests, the tree can take three basic states: healthy, drying, and overthrowing. Healthy and drying trees have the "dry" parameter that determines the percentage of drying in the crown. A healthy tree with a dry value of $0 \%$ has no signs of dryness. In the prediction process, when a tree is classified as dry, its state changes ("is_dry: = true"). From this moment, the tree participates in the process of decline. This block is responsible for controlling the tree's drying.

In addition, the current version of the FORKOME model has improved the appearance of trees and their textures in $3 \mathrm{D}$ visualization, which depicts the stages of shrinkage and decay of tree branches. Throughout the simulation process, changes have been tracked for each tree from its occurrence and annual growth to drying and falling out of the composition of the tree stand.

\section{Results}

General view of the test area at the beginning, in 2010 (Fig. 1a), and after 4 and 6 years of simulation, in 2014 (Fig. 1b) and in 2016 (Fig. 1c), respectively, with FORKOME model interface (Fig. 1d) was presented. At the beginning (Fig. 1a), there were 53 dry Norway spruce, but at the 6 years of model simulation time, its amount increased to 94 individuals and 20 trees were fall.

Within the analyzed plot, initially (in 2014), there were 245 trees. The trees belonging to Norway spruce ( 93 alive and 53 dry), fir (72 alive and 6 dry), sycamore (14 alive and 1 dry), and birch ( 6 alive) were recorded (Table 2). The FORKOME model has been verified using the 2014 and 2016 data and represents $90 \%$ field data concerning biomass in 2014 and $87 \%$ in 2016.

As a result of simulation, the proportion of Norway spruce trees considerably decreased. The sum of basal area value for Norway spruce was finally smaller $\left(1.9 \mathrm{~m}^{2} / \mathrm{ha}^{-1}\right)$ than for fir $\left(26.2 \mathrm{~m}^{2} / \mathrm{ha}^{-1}\right)$. In terms of numbers, Norway spruce trees almost decreased compared to those in the beginning (146 Norway spruce trees) of simulation and reached 42 . The number of fir trees increased to 125 individuals (Table 3).

Regarding the sum of basal area value, a distinct domination of fir is visible, supplemented with young and many beech trees (Table 3). For this forest plot, the Monte Carlo simulation runs were conducted in control conditions and in warm-dry climate changes scenario.

$\mathrm{T} \mathrm{a} \mathrm{b} \mathrm{l} \mathrm{e} \mathrm{2.} \mathrm{Initial} \mathrm{characteristics} \mathrm{of} \mathrm{alive} \mathrm{and} \mathrm{dry} \mathrm{trees} \mathrm{in} \mathrm{the} \mathrm{FORKOME} \mathrm{model.}$

\begin{tabular}{|l|c|c|c|}
\hline Species & Tree number & Basal area $\left(\mathbf{m}^{\mathbf{2}} / \mathbf{h a}^{-\mathbf{1}}\right)$ & Age (years) \\
\hline Picea abies & 146 & 26.5 & 77 \\
\hline Abies alba & 78 & 19.1 & 56 \\
\hline Acer pseudoplatanus & 15 & 4.9 & 82 \\
\hline Betula pendula & 6 & 1.4 & 72 \\
\hline
\end{tabular}




\section{Forkome}

Area Settings Analysis Window Help

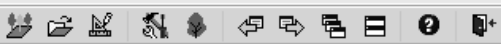

Area: Drying out spruce stands

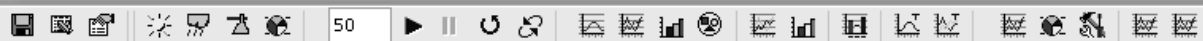

Drying out spruce stands : Sensitivity analysis - Crosscorrelation

d
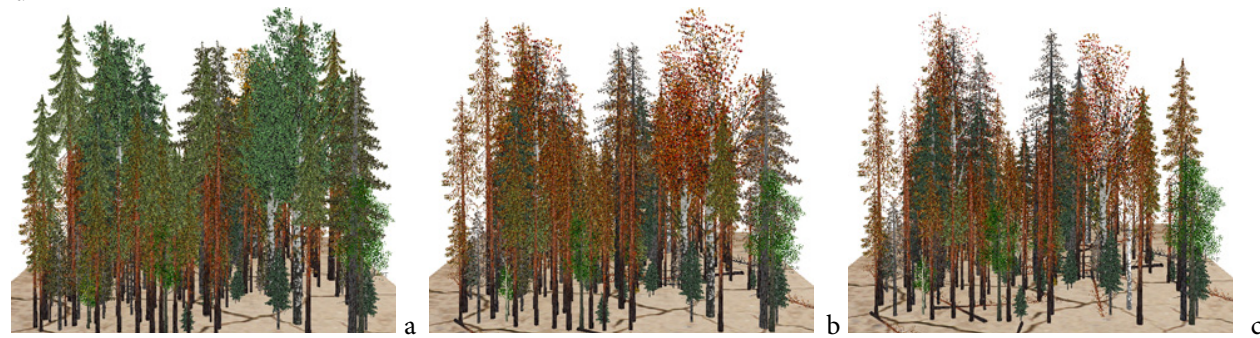

Fig. 1. View of the test plot at the beginning, in 2010 (a); at the 4th year of simulation, in 2014 (b); and at the 6th year of simulation, in 2016 (c), of the forecast with FORKOME model interface (d).

T a b le 3. Parameters of tree stand in the 100th year of simulation by the FORKOME model.

\begin{tabular}{|l|c|c|c|}
\hline Species & Tree number & Basal area $\left(\mathbf{m}^{\mathbf{2}} / \mathbf{h a} \mathbf{-}^{-\mathbf{}}\right)$ & Age (years) \\
\hline Picea abies & 42 & 1.9 & 61 \\
\hline Abies alba & 125 & 26.2 & 84 \\
\hline Fagus silvatica & 75 & 3.1 & 56 \\
\hline Acer pseudoplatanus & 5 & 3.2 & 168 \\
\hline
\end{tabular}

In Monte Carlo realization (200 simulations) for the control conditions, the FORKOME model predicted that the biomass of Norway spruce trees decreased from $153.57 \pm 5.6 \mathrm{t} / \mathrm{h}$ in the first years of model time to $32.0 \pm 3.2 \mathrm{t} /$ ha in 10 years (Fig. 2). After that the model predicts that Norway spruce would be at the same level up to 70 years and decrease to $11.3 \pm$ $2.6 \mathrm{t} / \mathrm{h}$ in 100 years. After the decrease in fir biomass in 10 years from $116.36 \pm 4.7 \mathrm{t} / \mathrm{h}$ in the first year of model time to $59.5 \pm 2.2 \mathrm{t} / \mathrm{ha}$ in 10 years, the model predicts that in 100 years, the fir biomass increased to $152.0 \pm 4.2 \mathrm{t} / \mathrm{ha}$. The FORKOME model predicts an increase in of beech biomass (to $38.5 \pm 3.6 \mathrm{t} / \mathrm{h}$ ) in the simulation time. The biomass of sycamore will be at the level of $22.8 \pm 1.7 \mathrm{t} / \mathrm{h}$ in 100 years and that of birch decreased to zero in 10 years of simulation times (Fig. 2).

In the control, the model predicted a decrease (from 93 at the beginning of simulation to 26 in 10 years) in the tree numbers of alive Norway spruce trees. After that the Norway spruce numbers increased to 42 individuals in 100 years. The number of fir trees decreased from 72 at the beginning to 44 in 10 years and increased to 119 individuals in 100 years. The numbers of beech trees increased to 84 individuals in 100 years (Fig. 3).

The prediction of simulation of dead trees showed intensive dying of Norway spruce and also fir trees, which was visible up to 10 years of simulation time. 


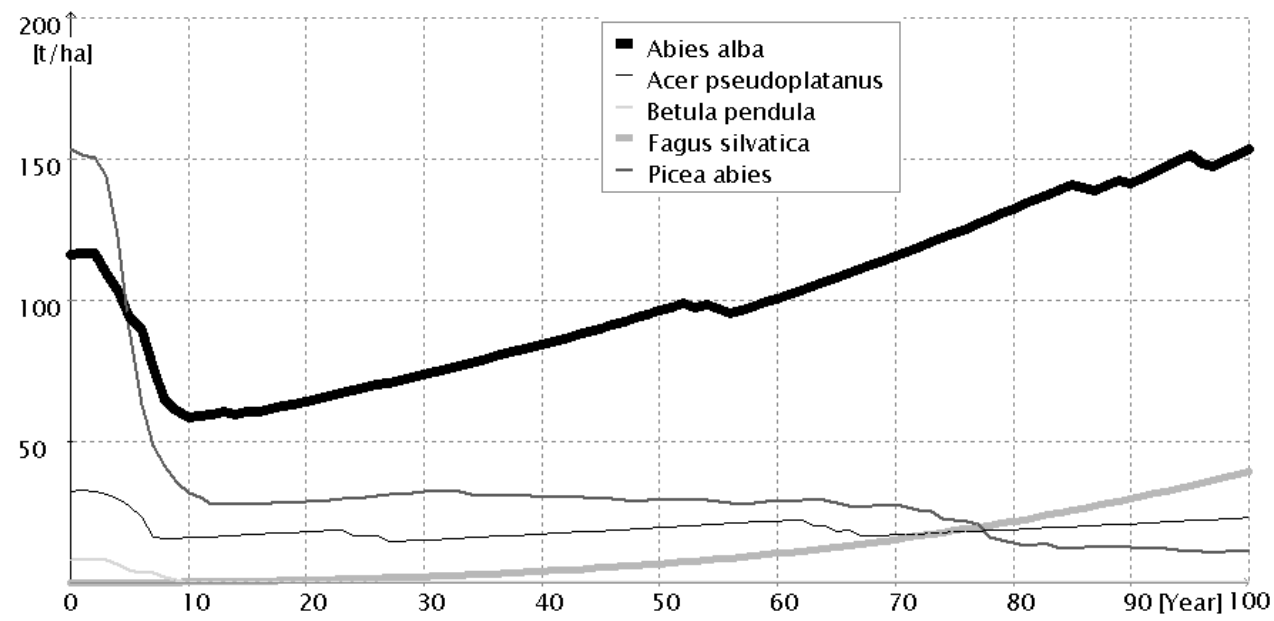

Fig. 2. Prediction of the biomass in control scenario.

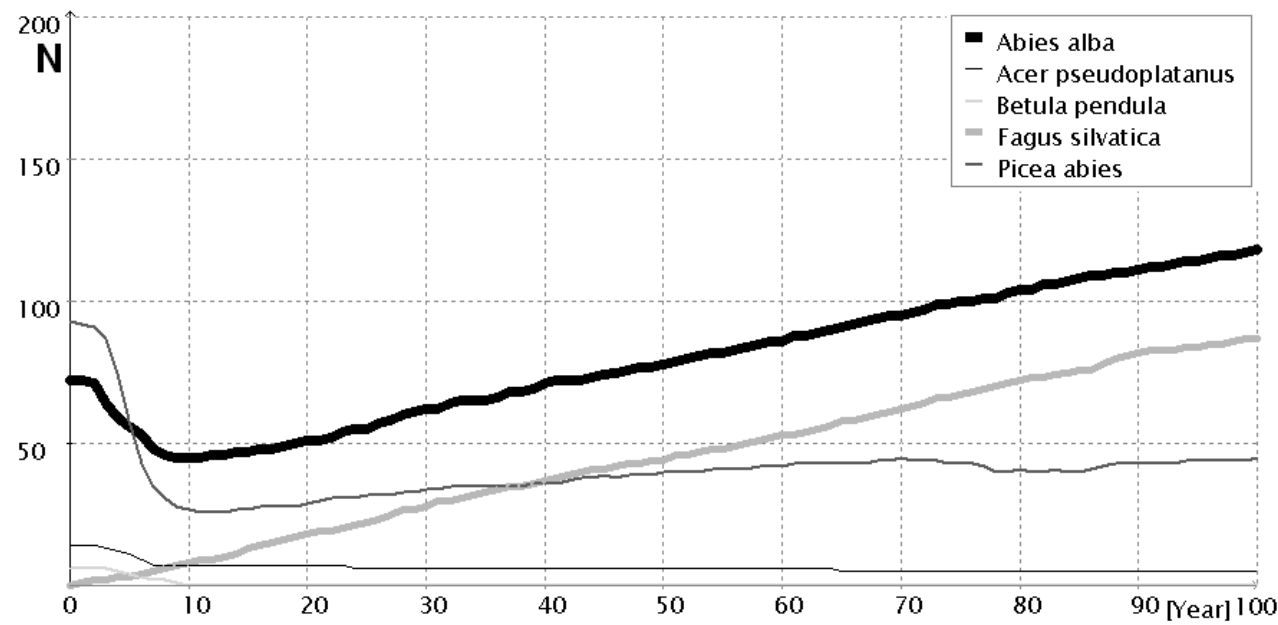

Fig. 3. Prediction of the number of trees in control scenario.

In warm-dry scenario, the model predicted that the biomass of Norway spruce trees decreased from $153.57 \pm 5.6 \mathrm{t} / \mathrm{h}$ in the first years of model time to $0.62 \pm 0.09 \mathrm{t} / \mathrm{h}$ in 16 years. After decreasing, the Norway spruce biomass will be at the minimum level of $0.5 \pm 0.1 \mathrm{t} / \mathrm{h}$ in 100 years. The model also predicts the decrease in fir (from $116.4 \pm 4.4 \mathrm{t} / \mathrm{h}$ in the first year of model time to $17.3 \pm 1.2 \mathrm{t} / \mathrm{h}$ in 10 years) and its increase in biomass to $27.1 \pm 2.4 \mathrm{t} / \mathrm{h}$ in 100 years. In the warm-dry climate changes scenario, the model predicted an increase in beech biomass (from zero at the beginning of simulation to $36.14 \pm 2.6 \mathrm{t} / \mathrm{h}$ biomass in 100 years). 


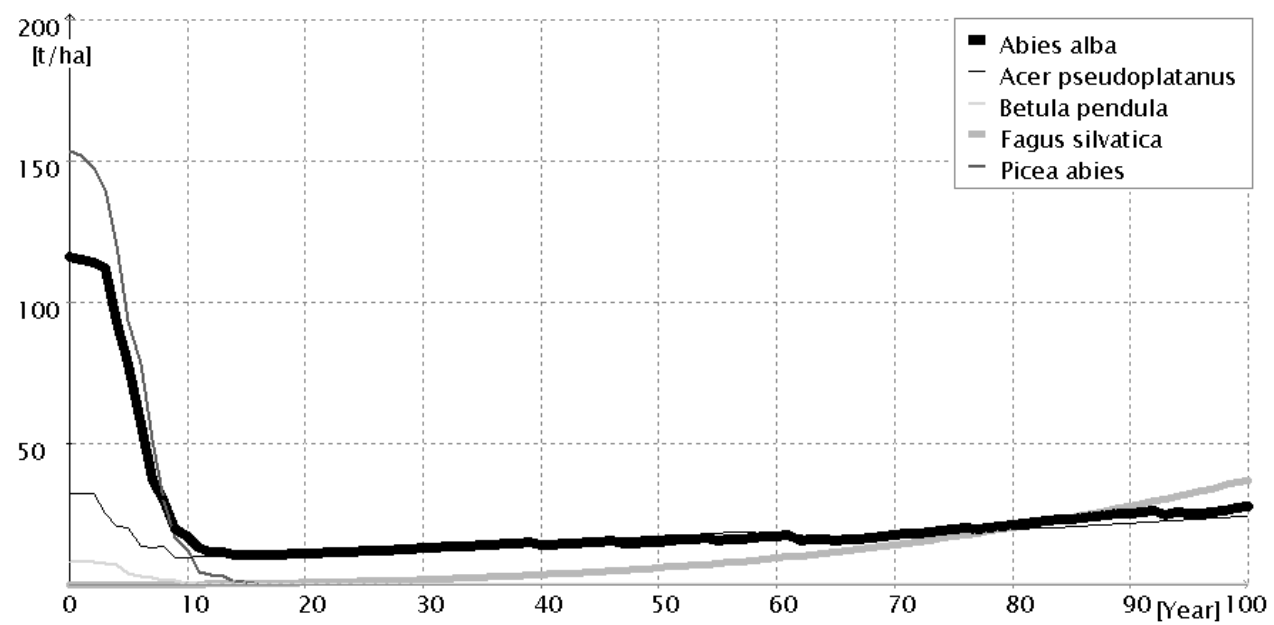

Fig. 4. Prediction of the biomass in warm-dry climate changes scenario.

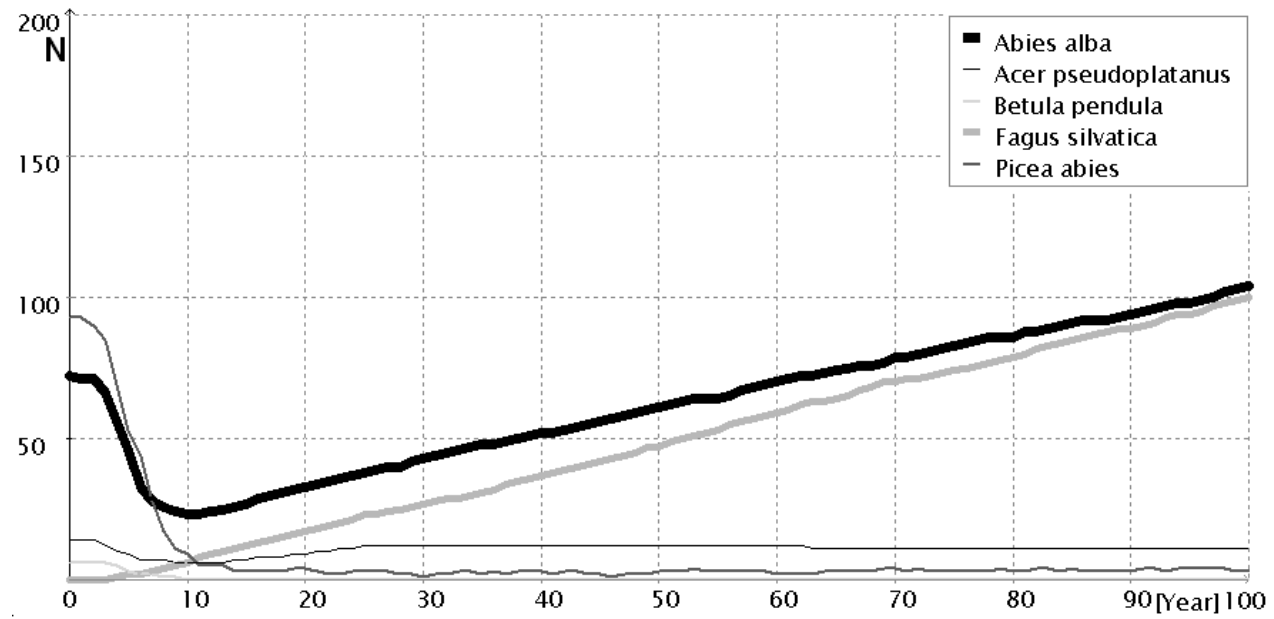

Fig. 5. Prediction of the amount of trees in warm-dry climate changes scenario.

The biomass of sycamore oscillates from $32.36 \pm 2.1 \mathrm{t} / \mathrm{h}$ at the beginning to $24.12 \pm 1.7$ in the 100 year. The biomass of birch decreased to zero in 10 year of simulation times (Fig. 4).

In warm-dry scenario, the tree numbers of Norway spruce decreased from 93 individuals in the first year to 6 individuals in 10 years and to 5 in 100 years of simulation time. After decreasing in the first 10 years, the amount of fir individuals increased to 105 in 100 years. The tree numbers of beech increased to 99 individuals in 100 year. On the plot, the number of sycamore individuals changes to 10 individuals in 100 years (Fig. 5). 
As a result of simulation in warm-dry scenario, the proportion of Norway spruce trees decreased more compared to the control conditions. The sum of basal area value for Norway spruce was finally smaller $(0.008$ $\left.\mathrm{m}^{2} \mathrm{ha}^{-1}\right)$ than that for fir (4.4 $\left.\mathrm{m}^{2} \mathrm{ha}^{-1}\right)$. In terms of numbers, Norway spruce trees almost decreased compared to those at the beginning of simulation and to those in the control conditions.

The autocorrelation of Norway spruce biomass and Norway spruce tree amount in FORKOME model simulations in control conditions and warmdry scenario was analyzed. The autocorrelation of Norway spruce concerning the biomass of trees is more positive than that concerning the amount of trees in control conditions (Fig. 6a). Generally, the autocorrelation of Norway spruce concerning the biomass and the amount of trees was not more changed in warmdry scenario (Fig. 6b) compared to the control conditions. The autocorrelations of Norway spruce in control conditions and in warm-dry scenario changed a little ( $\tau=3$ for the biomass and $\tau=2$ for the amount of trees in control conditions; and $\tau=3$ for the biomass and for the amount of trees in the warm-dry conditions on the level more than +0.75 ). The autocorrelations for birch and sycamore were similar to the autocorrelation of Norway spruce.
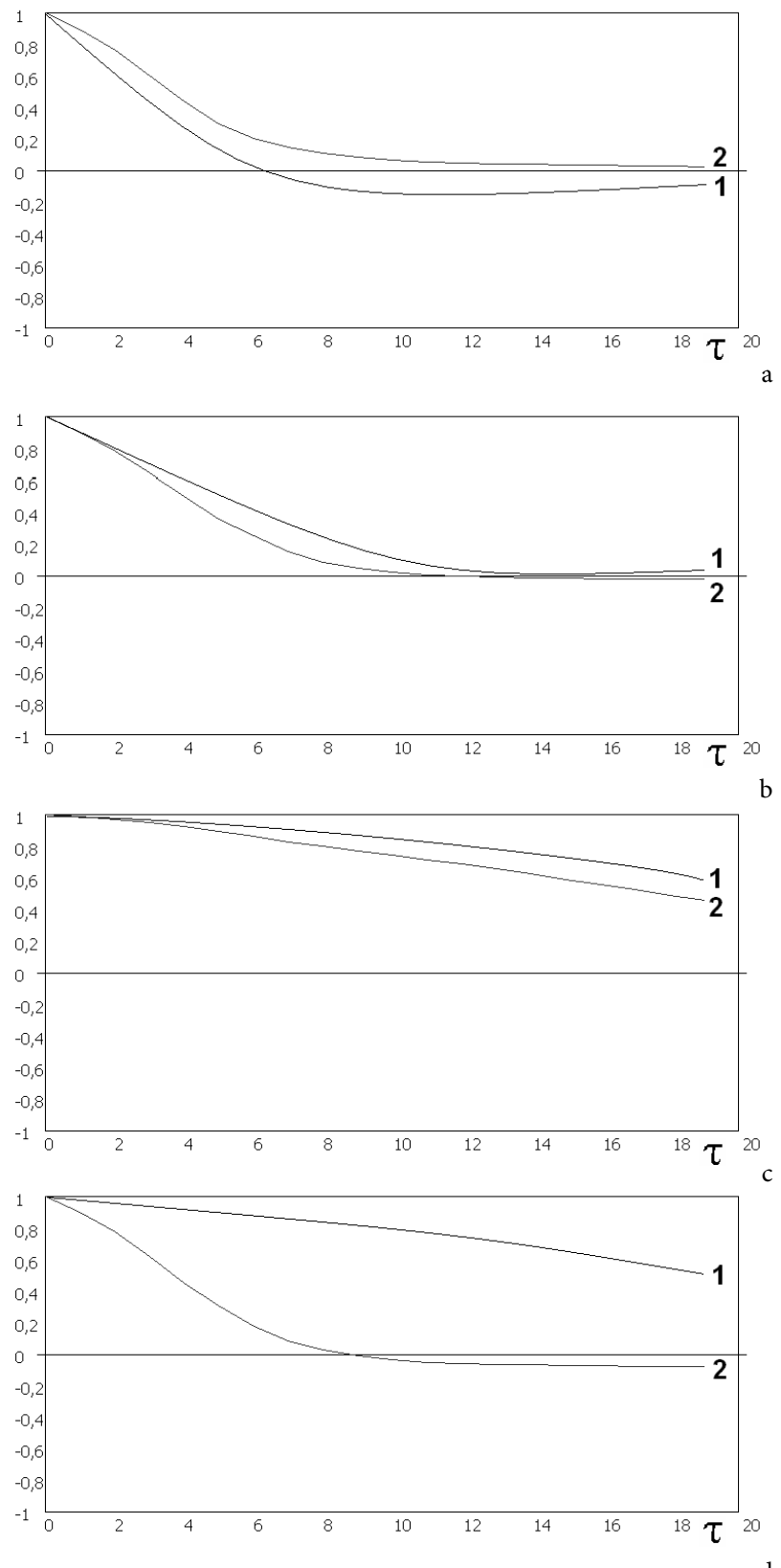

Fig. 6. Autocorrelation of amount of trees (1) and biomass (2) for Norway spruce in control conditions (a) and in warm-dry scenario (b) and for fir in control conditions (c) and in warm-dry scenario (d). 


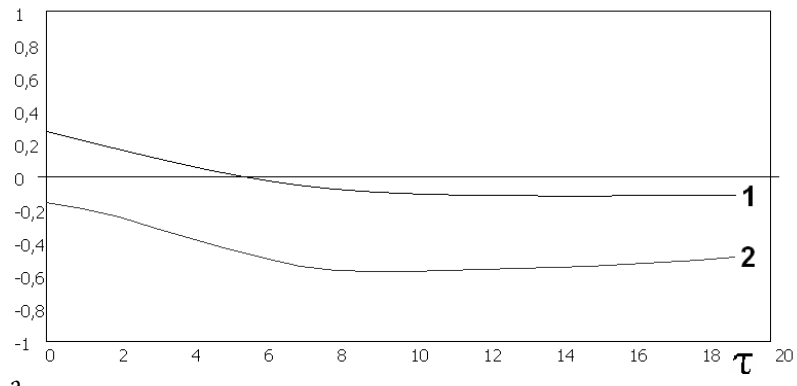

a

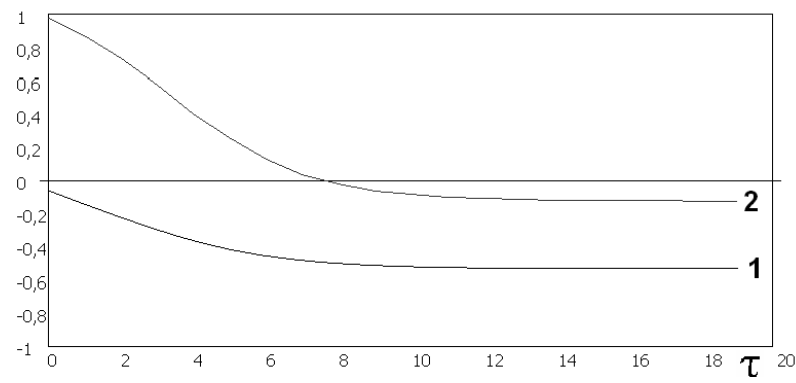

b

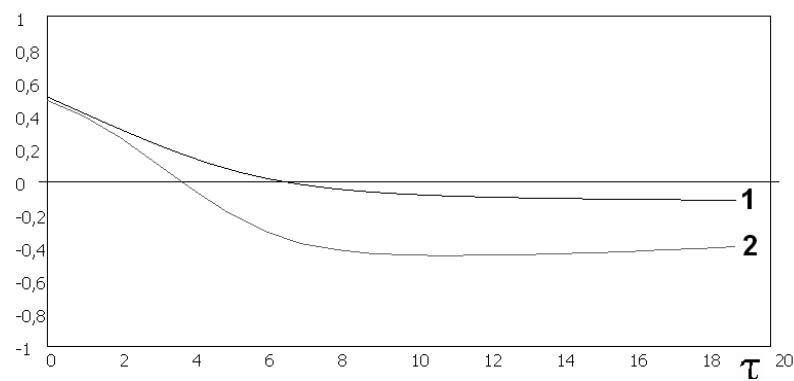

C

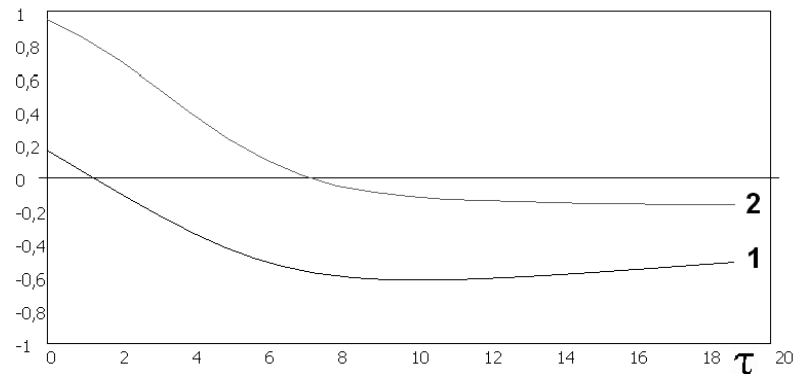

d

Fig. 7. Cross-correlation between Norway spruce and fir amount of trees (1) and biomass (2) in control conditions (a) and in warm-dry scenario (b) and between Norway spruce and total stand community in control conditions (c) and in warm-dry scenario (d).
For fir in control conditions (Fig. 6c), the autocorrelations of biomass and amount of trees were strong $(\tau=10$ for biomass and $\tau=14$ for amount of trees on the level more than +0.75 ). Only the autocorrelations of biomass of fir trees were less $(\tau=3$ on the level more than +0.75 ) in warm-dry climate changes scenario (Fig. $6 d)$.

The cross-correlation between Norway spruce and fir, Norway spruce and beech, Norway spruce and sycamore, and Norway spruce and birch was analyzed using the FORKOME model. In the control scenario, the cross-correlation between Norway spruce and fir biomass of trees was negative (Fig. 7a). It can mean that the relation between Norway spruce and fir were competitive. In warm-dry climate changes scenarios, the crosscorrelation between Norway spruce and fir biomass of trees changed from strong positive ( $\tau=2$ on the level more than +0.75 ) to weak negative (Fig. 7b) and the cross-correlation changed from +0.9 to -0.1 .

The cross-correlation is similar between the Norway spruce biomass in comparison with total tree stand biomass and also between tree amounts of Norway spruce in comparison with total tree amount on the stand community. This confirms a small influence of 
Norway spruce on all stand community in control conditions (Fig. 7c) and in warm-dry scenario (Fig. 7d).

The results of species biomass simulations during 100 years have been processed in statistical program. The multiple regression analysis for the biomass of Norway spruce, fir, beech, birch, and sycamore was conducted using Statistica 13.1 program.

After statistical processing of the results of simulation data, a mathematical equation has been obtained, which characterizes the connections that appear between the biomass of selected species. Here we only remark that the collected data have been analyzed for the dependent indicators in order to exclude cases that could violate the established regression equation. In the final result, after eliminating nonsignificant samples, the regression equation was determined. All indicators have been checked for the probability test $\mathrm{p} \leq 0.05$ in order to exclude those that showed a lack of statistical accuracy.

The statistically significant results with $\mathrm{p} \leq 0.05$ have been obtained for all analyzed parameters, and zero values of $p$ have been obtained in the results of regression analysis for the dependent variable Norway spruce biomass.

The analysis of the standardized residuals for the dependent variable showed a lack of values of greater than \pm 3 sigma, indicating a lack of significant data deviations.

For the analyzed control conditions, the prediction equation for Norway spruce biomass was given as follows: Picea abies $=-4,89563624765-1,34717188084^{*}$ "Fagus silvatica" $+0,246$ $197902646^{\star ”}$ Abies alba”+10,654894521* “Betula pendula”+1,11558300704*”Acer pseudoplatanus".

In warm-dry climate scenario, the prediction equation for Norway spruce was given as follows: Picea abies $=-5.92447769934-0.373233236774 *$ "Fagus silvatica" $+1.35232848217^{\star "}$ " Abies alba"+2.88879103231* “Betula pendula"-0.759108581137*"Acer pseudoplatanus".

These equations can be used for the calculation of Norway spruce biomass in situation where the FORKOME model will not be available and to compare with biomass prediction changes in the FORKOME Monte Carlo simulation run.

\section{Discussion}

The article presents the perspectives for the application of FORKOME computer model in prognosis of the impact of natural disturbances on Norway spruce forests. The FORKOME model, in its latest version, includes a recently created and constantly developed block of forest drying. As a result, it is possible to simulate potential changes caused by decline, and thus it predicted the impact of this disturbance agent on forest conditions and stand regeneration by conducting simulations on the issues concerned.

The model FORKOME uses both general mathematical relationships functioning within a forest ecosystem and empirical ones, characteristic for tree stands within analyzed plots. That is, it combines ecological models as well as empirical ones (Brzeziecki, 1999; Bugmann, 2001). On the basis of the results generated using the FORKOME model, the hypothesis that in 10 years of simulation time run, the Norway spruce may not be the dominant species within the analyzed area regarding the number of trees as well as their biomass seems reasonable. This indirectly confirms the Norway spruce in Gorgans area is in damage of forest 
associations there. The results obtained also suggested that even smallest climate changes, especially in air temperature and rainfalls, can cause decrease in the Norway spruce biomass and amount of trees. It is consistent with the data presented in literature. For example, Debrynuk (2011) reported that in connection with further climate change, the consequence of which is the gradual increase in the average annual temperature of the air and decrease in rainfall, increasing the length of the growing season, the drying of Norway spruce in the forest region will continue. In beech and fir-beech forest types that are intensified by natural regeneration beech forest, the best conditions for growth will be for sycamore and Silver fir. Similar results were presented in our FORKOME model simulations. It means that we can introduce promising species into existed forest stand composition, which can provide the highest stability and productivity of phytocoenosis, as proposed by Debrynuk (2011).

Unfortunately, in the countries of Western Europe, there were only small remains of natural forests. In this regard, virgin forests in the Ukrainian Carpathians and their research are extremely important for the close-to-nature forestry management throughout Europe. The goal of the approaching nature of forestry is the forestry method by which various goals can be achieved. Stable, close to natural, forests can in the long run meet different expectations.

In the Ukrainian Carpathians, computer simulation using the FORKOME model is perspective. The FORKOME model predicted decreases in Norway spruce biomass and amount of trees and increase in Silver fir and Common beech. This once again emphasizes the relevance of introducing sustainable forest management methods that increase the sustainability of forests.

Parpan et al. (2014) also confirmed that secondary Norway spruce forests' decline is very intensive in the Ukrainian Carpathians now on the area of 19,300 ha of forests with a wood volume of nearly 5.8 million $\mathrm{m}^{3}$. The main reason is Norway spruce stand stability deterioration because of global warming, Norway spruce planting in the not typical for Norway spruce forest sites, environmental pollution, the massive spread of the Norway spruce diseases and pests, and the Norway spruce stands' damages by windfalls and snow. Excessive distribution of the Norway spruce decline areas and Norway spruce forests stability deterioration together with Norway spruce forests increment decreasing require emergency management activities based on the forest typology, the forest monitoring results, and the economic conditions analysis.

This will help to slow up the rapid degradation of Norway spruce stands, what reduces their protective, water-reserve, ecological and recreational functions, and what leads to a wood resources loss and a fire risk increases in these forest stands.

\section{Conclusion}

A sharp decrease in the biomass of decline Norway spruce stand was showed in the first decade for 100 years simulation in control conditions and warm-dry scenario. The biomass of Norway spruce trees decreased from $153.57 \mathrm{t} / \mathrm{h}$ in the first years of model time to $11.3 \mathrm{t} / \mathrm{h}$ in 100 years in control conditions and to $0.5 \mathrm{t} / \mathrm{h}$ in warm-dry scenario. The Norway spruce was especially sensitive to changing climatic conditions. Its share and biomass were decreased in control conditions and in warm-dry scenarios. The fir, beech, and sycamore were characterized by a much better adaptation to warmer and drier conditions for the next decades. 
Improvement in the FORKOME model provides grounds for arguing about the possibility and expediency of working out forecast predictions for the development of dwindling Norway spruce stands. Scientific research is based on the need for earlier warnings about threats to forest ecosystems in order to minimize the costs of their restoration. Thus, the urgency and necessity of investigations of the current sanitary condition of Norway spruce trees and their forecasting with the use of computer simulation software are emphasized.

Improving the health condition of Norway spruce forests is possible by gradually changing the structure and species composition. The correct solution will be to introduce species that are more resistant, such as fir, and deciduous trees, such as beech, that were presented in the article and in the FORKOME model simulations.

The condition for proper management of mountain Norway spruce forests is to understand their natural disturbances of dynamics at the stand level. Such information is the basis on which sustainable forest practices can be developed.

\section{References}

Botkin, D.B. (1993). Forest dynamics: an ecological model. Oxford, New York: Oxford University Press.

Brzeziecki, B. (1999). Ecological model of the forest stand. Principles of construction, parameterization, examples of application (in Polish). Ph.D. Thesis, Warszawa.

Bugmann, H. (2001). A review of forest gap models. Clim. Change, 51, 259-305. DOI: 10.1023/A:1012525626267.

Debrynuk, Yu M. (2011). Die-back of the fir forests: causes and consequences (in Ukrainian). Науковий вісник НЛТУ України, 21(16), 32-38.

Durło, G. (2011). The possibility of adaptation of spruce forests in Beskid Śląski Mts. to changing climatic conditions (in Polish). Prace i Studia Geograficzne, 47, 227-236.

Fabrika, M. (2005). Simulator biodynamiky lesa SIBYLA, koncepcia, konštrukcia a programove riešenie. Ph.D. Thesis, Technicka univerzita vo Zvolen.

Frazer, G.W., Canham, C.D. \& Lertzman K.P. (2000). Gap Light Analyzer (GLA), Version 2.0: Image processing software to analyze true-colour, hemispherical canopy photographs. Bull. Ecol. Soc. Am., 81, 191-197. DOI: 10.1890/0012-9623(2000)081[0190:TT]2.0.CO;2.

IPCC (2007). Climate Change 2007: Synthesis report. In Core Writing Team, R.K. Pachauri \& A. Reisinger (Eds.), Contribution of working groups I, II and III to the fourth assessment report of the intergovernmental panel on climate change. Geneva: IPCC.

Grodzki, W., Starzyk, J. \& Kosibowicz M. (2014). Impact of selected stand characteristics on the occurrence of the bark beetle Ips typographus (L.) in the Beskid Żywiecki Mountains (in Polish). Leśne Prace Badawcze, 75(2), 159-169. DOI: 10.2478/frp-2014-0015.

Holubets, M. (1978). Spruce forests of Ukrainian Carpathians (in Ukrainian). Nauka.

Jørgensen, S.E. (1994). Fundamentals of ecological modelling. Amsterdam, London, New York, Tokyo: Elsevier.

Kozak, I., Chłódek, D., Zawadzki, A., Kozak, H. \& Potaczała G. (2007). Simulation of spruce forest reconstruction in the Polish Bieszczady using the FORKOME model (in Polish). Leśne Prace Badawcze, 2, 7-26.

Kozak, I. \& Menshutkin V. (2001). Investigation of spruce forest dynamics in the Bieszczady Mountains using a computer modelling. Ekológia (Bratislava), 20(4), 371-378.

Kozak, I. \& Menshutkin V. (2002). Predictions of spruce forest dynamics in the Polish Bieszczady and Ukrainian Bieskidy using the computer modelling. Baltic Forestry, 8(1), 28-34.

Kozak, I., Mikusiński, G, Stępień, A., Kozak, H. \& Frąk R. (2012). Modelling forest dynamics in a nature reserve: a case study from south-central Sweden. J. For. Sci., 58(10), 436-445. DOI: 10.17221/28/2012-JFS.

Lavnyy, V. \& Schnitzler G. (2014). Conversion felling in the secondary spruce stands experiences in Germany (in Ukrainian). Proceedings of the Forestry Academy of Sciences of Ukrain, Collection of Research Papers, 12, 73-78.

Lindner, M., Maroschek, M., Netherer, S., Kremer, A., Barbati, A., Garcia-Gonzalo, J., Seidl, R., Sylvain Delzon, S., Corona, P., Marja Kolstro, M., Lexer, M. \& Marchetti M. (2010). Climate change impacts, adaptive capacity, and vulnerability of European forest ecosystems. For. Ecol. Manag., 259, 698-709. DOI: 10.1016/j.foreco.2009.09.023. 
Mandre, M., Annuka, E. \& Tuulmets L. (1992). Response reactions of conifers to alkaline dust pollution. Changes in the pigment system. Proc. Est. Acad. Sci. Biol. Ecol., 4, 156-173.

Parpan, V.I., Shparyk, Y.S., Slobodyan, P., Parpan, T., Korshov, V., Brodovich, R., Krynyckyi, G., Debrenyuk, Y., Kramarets, V. \& Cheban I. (2014). Forest management peculiarities in secondary Norway spruce (Picea abies (L.) H. Karst.) stands of the Ukrainian Carpathian (in Ukrainian). Proceedings of the Forestry Academy of Sciences of Ukraine, Collection of Research Papers, 12, 178-185.

Shparyk, Y.S. (2014). Form diversity and the health condition of Norway spruce (Picea abies (L.) Karst.) in the main forest types of the Ukrainian Carpathians (in Ukrainian). Forestry and Forest Melioration, 125, 87-96.

Shparyk, Y.S. (2019). Ecological results of Norway spruce forests' decline in main forest types of the Ukrainian Carpathians (in Ukrainian). Proceedings of the Forestry Academy of Sciences of Ukraine, 18, 145-153. DOI: $10.15421 / 411915$.

Spiecker, H., Hansen, J., Klimo, E., Skovsgaard, J.P., Sterba, H. \& von Teuffel K. (2004). Norway spruce conversion options and consequences. European Forest Institute Research Report, 18, 25-62.

Turis, E.V. \& Shanta O.I. (2013). Status and perspectives of the content of derived conifer forest in the territory of National Park "Enchanted land" (in Ukrainian). Науковий вісник Ужгородського університету: Серія: Геограбія, Землеустрій, Природокористування, 2, 186-190. 